\title{
Effect of Ethanol on Polyamine Synthesis during Liver Regeneration in Rats
}

Anna Mae Diehl, Michael Wells, Nesbitt D. Brown, Snorri S. Thorgeirsson, and Clifford J. Steer

Department of Medicine, Veterans Administration Medical Center, Washington, DC, Biochemistry Division, Walter Reed Army

Institute of Research, Washington, DC, and The National Cancer Institute, National Institutes of Health, Bethesda, Maryland 20892

\begin{abstract}
Ethanol consumption retards the hepatic regenerative response to injury. This may contribute to the pathogenesis of liver injury in alcoholic individuals. The mechanisms responsible for ethanol-associated inhibition of liver regeneration are poorly understood. To determine if the antiregenerative effects of ethanol involve modulation of polyamine metabolism, parameters of polyamine synthesis were compared before and during surgically induced liver regeneration in ethanol-fed rats and isocalorically maintained controls. After partial hepatectomy, induction of the activity of ornithine decarboxylase (ODC), the rate limiting enzyme for polyamine synthesis, was delayed in rats that had been fed ethanol. This was correlated with reduced levels of putrescine, ODC's immediate product. Increases in hepatic spermidine and spermine were also inhibited. Differences in ODC activity between ethanol-fed and control rats could not be explained by differences in the expression of ODC mRNA or by differences in ODC apoenzyme concentrations, suggesting that chronic ethanol intake inactivates ODC posttranslationally. Supplemental putrescine, administered at partial hepatectomy and 4 and 8 h thereafter, increased hepatic putrescine concentrations and markedly improved DNA synthesis and liver regeneration in ethanol-fed rats. These data suggest that altered polyamine metabolism may contribute to the inhibition of liver regeneration that occurs after chronic exposure to ethanol. (J. Clin. Invest. 1990. 85:385-390.) alcohol • DNA • ornithine decarboxylase • proliferation $\bullet$ putrescine
\end{abstract}

\section{Introduction}

There is evidence that ethanol inhibits hepatic DNA synthesis and liver regeneration (1-7). Since liver regeneration is important for recovery from many forms of liver injury (8-11), the antiregenerative effects of ethanol may contribute to the pathogenesis and progression of liver disease in alcoholic individuals. The mechanisms by which ethanol inhibits liver regeneration are unknown but may be important to understand in order to design successful treatments for alcoholic liver disease.

Regulation of regenerative growth is, in general, poorly understood. However, it is known that polyamine synthesis is

Presented in part in abstract form at the Annual Meeting for the American Association for the Study of Liver Diseases, November 1988.

Address reprint requests to Dr. Diehl, Gastroenterology Division151W, Veterans Administration Medical Center, 50 Irving Street, NW, Washington, DC 20422.

Received for publication 17 April 1989 and in revised form 22 September 1989.

The Journal of Clinical Investigation, Inc.

Volume 85, February 1990, 385-390 required for regeneration in a number of tissues, including the liver (12-14). Polyamines have been implicated as regulators of both DNA $(15,16)$ and protein $(17,18)$ synthesis and may also affect the expression of genes which regulate cell division $(19,20)$. Biosynthesis of the polyamines (putrescine, spermidine, and spermine) is controlled by the activity of ornithine decarboxylase (ODC), ${ }^{1}$ the first and rate limiting enzyme of the pathway, as well as by the availability of ornithine, the substrate of ODC (14).

The antiproliferative effects of ethanol may be mediated, at least partly, by inhibition of polyamine synthesis. In support of this belief are data that acute exposure to ethanol inhibits ODC activity $(21,22)$, as well as the availability of ornithine (23). In opposition to it are observations that ODC activity is apparently unaffected by chronic ethanol consumption $(24,25)$.

It is known that chronic consumption of ethanol inhibits DNA synthesis and liver regeneration $24 \mathrm{~h}$ after partial hepatectomy $(2-5,25)$. One purpose of the present study was to determine if polyamine synthesis is also inhibited under identical conditions. To answer this question, several parameters of polyamine metabolism were compared in ethanol-fed rats and isocalorically maintained controls before and at various times during the first $24 \mathrm{~h}$ after partial hepatectomy. Secondly, in order to determine if ethanol-associated alterations in polyamine synthesis contribute to ethanol's inhibition of liver regeneration, the ability of supplemental putrescine to improve regeneration in ethanol rats was tested.

\section{Methods}

Materials. The 1982 formulations of the Lieber de Carli ethanol and control diets were purchased from Bio-Serv (Frenchtown, NJ). In each liter of control diet, fat contributes $350 \mathrm{kcal}$, protein $180 \mathrm{kcal}$, and carbohydrate $470 \mathrm{kcal}$. The ethanol diet is identical except ethanol is substituted for 355 of the carbohydrate calories. All chemicals used in HPLC, DNA, and enzyme assays were from Sigma Chemical Co. with the exception of $\left[1-{ }^{14} \mathrm{C}\right]$ ornithine, $\left[{ }^{3} \mathrm{H}\right]$ thymidine, and $\left[{ }^{3} \mathrm{H}\right]$ difluoromethylornithine (DFMO) which were purchased from DuPont-New England Nuclear (Boston, MA). Reagents for determination of hepatic protein content were purchased from Bio-Rad Laboratories (Richmond, CA). The prepacked $300 \times 3.9 \mathrm{~mm}$ i.d. $\mu$ Bondapak $\mathrm{C} 18 \mathrm{col}-$ umn used for HPLC separation of polyamines was from Waters Associates (Milford, MA).

Animals. 108 adult male Wistar-Furth rats (mean initial weight $\sim 150 \mathrm{~g}$ ) were divided into two groups. One group (ethanol fed, $n$ $=54$ ) was fed a liquid chow diet in which ethanol contributed $36 \%$ of the total calories. A second group (pair fed, $n=54$ ) was fed isocaloric quantities of the same diet but dextrin-maltose was substituted for ethanol (26). Although such "pair feeding" restricts the caloric intake of the control group, previous studies have demonstrated no significant differences in ODC activity or DNA synthesis before or $24 \mathrm{~h}$ after partial hepatectomy in pair-fed rats and rats allowed ad lib. access to

1. Abbreviations used in this paper: ASGP, asialoglycoprotein; DFMO, $\left[{ }^{3} \mathrm{H}\right]$ difluoromethylornithine; ODC, ornithine decarboxylase; $\mathrm{PH}$, partial hepatectomy; PLP, pyridoxal 5'-phosphate. 
chow (25). Therefore, ad lib.-fed controls were not included in the present experiments. The animals were housed in individual cages with a 12-h light and 12-h dark cycle and fed their respective diets for $6 \mathrm{wk}$. During that period of time dietary intake and body weight were monitored. Previous studies in our laboratory have shown that under such conditions $(a)$ ethanol and control rats grow comparably; $(b)$ midmorning blood ethanol levels range from 75 to $150 \mathrm{mg} / \mathrm{dl}$ and $(c)$ the ethanol diet produces hepatic steatosis without significant necroinflammation or fibrosis (25). These results are similar to those of others utilizing this dietary protocol (26).

After $6 \mathrm{wk}$ on the respective diets, the animals underwent a $70 \%$ partial hepatectomy (PH) with light ether anesthesia between 9 and 11 a.m. (27). Partial hepatectomy has been shown to substantially increase the proportion of hepatocytes in S phase and is therefore a standard technique used to assess the response to various effectors of regeneration (28). Sham-operated controls were not included in these experiments since a previous study has demonstrated that the effects of partial hepatectomy on DNA synthesis and ODC activity are not reproduced by sham laparotomy (25).

At various times $(0.5,1,3,6,12$, or $24 \mathrm{~h})$ postoperatively, the liver remnants were resected and the rats were killed by exsanguination under light ether anesthesia. The livers were immediately weighed and freeze clamped in liquid nitrogen. The tissues were stored at $-70^{\circ} \mathrm{C}$ for up to $2 \mathrm{wk}$, until they were analyzed for ODC activity, polyamine levels, ODC mRNA expression, ODC apoenzyme concentration, and total protein content.

In separate experiments 60 similar rats were fed either ethanol ( $n$ $=45)$ or control $(n=15)$ diets for $6 \mathrm{wk}$ as described above. At the time of partial hepatectomy and 4 and $8 \mathrm{~h}$ thereafter, these rats received intraperitoneal injections of either normal saline or putrescine ( 1 or 4 $\mathrm{mg} / \mathrm{kg}$ body $\mathrm{wt}) .1 \mathrm{~h}$ before death they were injected intraperitoneally with $\left[{ }^{3} \mathrm{H}\right]$ thymidine $(10 \mu \mathrm{Ci} / 200 \mathrm{~g}$ rat $)$. Rats were killed $24 \mathrm{~h}$ after partial hepatectomy and livers were immediately weighed, frozen with liquid nitrogen, and saved at $-70^{\circ} \mathrm{C}$ subsequent analysis of $\left[{ }^{3} \mathrm{H}\right]$ thymidine incorporation by scintillation counting and autoradiography, DNA and protein content and polyamine concentrations.

Determination of ODC activity. ODC activity was measured in liver homogenates by the quantitation of ${ }^{14} \mathrm{CO}_{2}$ liberated from $\left[{ }^{14} \mathrm{C}\right]-$ ornithine using a modification (25) of the method described by Luk and Baylin (29). Briefly, the livers were homogenized 1:10 (wt/vol) in $100 \mathrm{mM}$ sodium phosphate buffer, $\mathrm{pH} 7.2$, containing $5 \mathrm{mM}$ DTT and centrifuged at $100,000 \mathrm{~g}$ for $20 \mathrm{~min}$. The final reaction mixture $(500 \mu \mathrm{l})$ contained $100 \mu \mathrm{M}$ unlabeled ornithine, $1 \mu \mathrm{Ci} \mathrm{L}-\left[1-{ }^{-14} \mathrm{C}\right]$ ornithine hydrochloride $(20 \mathrm{mCi} / \mathrm{mmol}$, New England Nuclear), $100 \mu \mathrm{M}$ pyridoxal phosphate and $300 \mu \mathrm{l}$ of supernatant. The reaction mixture contained abundant pyridoxal phosphate to minimize underestimation of the amount of apoenzyme present due to in vitro cofactor deficiency. Both reagent blanks and heated homogenate blanks were routinely included in the assay to control for ODC-independent, nonspecific decarboxylation of $\left[{ }^{14} \mathrm{C}\right]$ ornithine. The reactions were run in capped, $25-\mathrm{ml}$ vials incubated at $37^{\circ} \mathrm{C}$ in a shaking water bath for $30 \mathrm{~min}$. The reaction was terminated with $10 \%$ TCA. The ${ }^{14} \mathrm{CO}_{2}$ trapped on a filter impregnated with $2 \mathrm{M}$ hyamine hydroxide was assessed. Results are expressed as nanomoles of $\mathrm{CO}_{2}$ released/hour per milligram protein.

$O D C$ apoenzyme quantitation. In separate assays, ODC apoenzyme was quantitated in the aforementioned $100,000 \mathrm{~g}$ supernatants of liver homogenates by measuring the binding of tritium-labeled DFMO $\left(\left[{ }^{3} \mathrm{H}\right] D F M O\right)(30)$. As above, both reagent and boiled blanks were included in the assay. Separate controls incubated with the same amount of cold DFMO were assayed for residual ODC activity to insure that sufficient $\left[{ }^{3} \mathrm{H}\right] \mathrm{DFMO}$ had been added to completely inactivate the ODC present. The final reaction mixture $(110 \mu \mathrm{l})$ contained $25 \mu \mathrm{l}$ of supernatant, $100 \mu \mathrm{M}$ pyridoxal 5'-phosphate (PLP), and $1 \mu \mathrm{Ci}$ of $\left[{ }^{3} \mathrm{H}\right]$ DFMO $(20 \mathrm{Ci} / \mathrm{mmol}$; New England Nuclear). Binding was allowed to proceed in a shaking water bath at $37^{\circ} \mathrm{C}$ for $2 \mathrm{~h}$ before the reaction was terminated by the addition of $12 \%$ perchloric acid. Subsequently, the acid precipitates were filtered and the filters washed sequentially with $6 \mathrm{vol}$ of $12 \%$ perchloric acid, a mixture of ethanol/ chloroform/ether (2:1:1) and ether. Filters were then air dried and solubilized with soluene. Radioactivity of the solubilized protein was determined. Results are expressed as disintegrations per milligram protein.

Polyamine determination. A prepacked $300 \times 3.9 \mathrm{~mm}$ i.d., $10-\mu \mathrm{m}$ particle sized $\mu$ Bondapak C18 column was employed to chromatograph the dansylated polyamines. The mobile phase consisted of 0.02 M PIC B-7 reagent (1-heptanesulfonic acid) pumped in tandem with acetonitrile. Two high-pressure pumps were used to deliver the mobile phase. A concave gradient was used to elute the various polyamines from the column. Gradient parameters were 50\% acetonitrile and 50\% of the $0.02 \mathrm{M} 1$-heptanesulfonic acid at zero time. Upon injection, the acetonitrile was increased from 50 to $80 \%$ within a 20 -min period. Total analysis time was $30 \mathrm{~min}$. Flow rate for the dual pumping system was $2 \mathrm{ml} / \mathrm{min}$. Column pressures ranged between 75 and 85 bar. All separations were performed at room temperature. 1,6-Diaminohexane was used as an internal standard. Each specimen was run in triplicate to ensure reproducibility. Peak areas were measured by an on-line computing integrator. The detection limit of the method was $1 \mathrm{pmol}$ on column with a signal-to-noise ratio of 3:1. A fluoromonitor (Aminco, Rockville, MD), equipped with a $365-\mathrm{nm}$ excitation and 485-nm emission filter was employed for fluorometric detection (31). Results are expressed as picomoles of di- or polyamine/mg protein. Protein content was determined by the method of Bradford (32) using BSA as standard.

DNA probes. A 1,600-bp cDNA clone (clone pOD48) of mouse ornithine decarboxylase was supplied by Dr. P. Coffino, University of California, San Francisco (33). A 1,169 bp cDNA clone (clone 22) of the rat liver asialoglycoprotein receptor (ASGP) was supplied by $\mathrm{K}$. Drickamer, Columbia University (34).

$R N A$ isolation and Northern blotting. RNA isolation, poly $(\mathrm{A}+) \mathrm{RNA}$ enrichment and electrophoresis on horizontal denaturing formaldehyde-agarose gels with subsequent transfer to nitrocellulose membranes was performed as previously described (35). After prehybridization in the hybridization buffer for $5 \mathrm{~h}$ at $42^{\circ} \mathrm{C}$, nylon membranes were hybridized to ${ }^{32} \mathrm{P}$-nick-translated DNA probes (specific activity $1 \times 10^{8} \mathrm{cpm} / \mu \mathrm{g}$ DNA) overnight at $42^{\circ} \mathrm{C}$ in $50 \%$ deionized formamide, $5 \times \mathrm{SSC}(1 \times \mathrm{SSC}=0.15 \mathrm{M} \mathrm{NaCl} / 0.015 \mathrm{M}$ trisodium citrate), $5 \times \mathrm{E}$ buffer $(1 \times \mathrm{E}$ buffer $=10 \mathrm{mM}$ phosphate buffer, $\mathrm{pH} 7.5)$, $3 \times \mathrm{PM}(1 \times \mathrm{PM}=0.2 \%$ Ficoll, $0.02 \%$ polyvinylpyrrolidone and $0.02 \%$ BSA) and $0.1 \%$ SDS with $0.5 \mathrm{mg} / \mathrm{ml}$ yeast tRNA carrier. Blots were washed at moderate stringency $(2 \times \mathrm{SSC} / 0.1 \% \mathrm{SDS}$ at room temperature for $30 \mathrm{~min}$ with a total of three changes and $0.1 \times \mathrm{SSC} / 0.1 \%$ SDS at $45^{\circ} \mathrm{C}$ for $20 \mathrm{~min}$ with a total of two changes), and exposed to Kodak XAR-5 film with intensifying screens. After exposure to film, Northern blots were washed (boiled for $5 \mathrm{~min}$ in water) and reprobed with albumin, ASGP, and GAPDH cDNA probes to confirm that all lanes had equal amounts of RNA.

In vitro transcription and hybridization. Isolation of nuclei and transcription analysis were performed according to the method of J. A. Silverman and J. D. Yager (manuscript in preparation). In short, at specific times after $\mathrm{PH}$, samples of tissue were excised, frozen in liquid nitrogen and stored at $-70^{\circ} \mathrm{C}$ until analyzed. To obtain nuclei, $0.5 \mathrm{~g}$ of frozen liver fragments were pulverized in liquid nitrogen and Dounce homogenized in buffer containing $0.32 \mathrm{M}$ sucrose, $3 \mathrm{mM} \mathrm{MgC1} 2$ and $1 \mathrm{mM}$ Hepes, pH 6.8 and then centrifuged for $10 \mathrm{~min}$ at $1,000 \mathrm{~g}$ for $1 \mathrm{~h}$ at $4^{\circ} \mathrm{C}$. The crude nuclear pellet was layered onto a $2.1 \mathrm{M}$ sucrose, 1 $\mathrm{mM}$ Hepes, $\mathrm{pH} 6.8$, and $2 \mathrm{mM} \mathrm{MgCl}_{2}$ cushion and centrifuged at $70,000 \mathrm{~g}$ for $1 \mathrm{~h}$ at $4^{\circ} \mathrm{C}$. The nuclear pellet was gently resuspended and washed twice in $0.25 \mathrm{M}$ sucrose, $1 \mathrm{mM}$ Hepes, $\mathrm{pH} 6.8$, and $1 \mathrm{mM}$ $\mathrm{MgCl}_{2}$. The nuclei were then resuspended in transcription buffer containing $0.2 \mathrm{M}$ Tris- $\mathrm{HCl}, \mathrm{pH} 8.0,20 \%$ glycerol, $140 \mathrm{mM} \mathrm{KCl}, 5 \mathrm{mM}$ $\mathrm{MgCl}_{2}, 1 \mathrm{mM} \mathrm{MnCl} 2,14 \mathrm{mM} \beta$-mercaptoethanol and $1 \mathrm{mM}$ each of ATP, CTP, and GTP. An aliquot of $100 \mu \mathrm{Ci}$ of $\left[{ }^{32} \mathrm{P}\right] \mathrm{UTP}(3,000 \mathrm{Ci} /$ $\mathrm{mmol}$; New England Nuclear) was added to the suspension which was then incubated at $30^{\circ} \mathrm{C}$ for $25 \mathrm{~min}$ with periodic mixing. After recovering the nuclei by centrifugation at $1,000 \mathrm{~g}$ for $10 \mathrm{~min}$ at $4^{\circ} \mathrm{C}$, the nuclei were lysed in buffer containing $0.5 \mathrm{M} \mathrm{MgCl}_{2}, 0.5 \mathrm{M} \mathrm{NaCl}, 0.01 \mathrm{M}$ 
Tris-HCl, pH 7.4 and $100 \mu \mathrm{g} / \mathrm{ml}$ DNAse (RNAse free; Worthington Biochemical, Malvern, PA). RNA was extracted with phenol/chloroform and precipitated with ethanol. $2 \times 10^{6} \mathrm{cpm}$ of labeled RNA was hybridized to nylon filters (MSI, Westboro, MA) to which $1.0 \mu \mathrm{g}$ of the indicated probe fragment was bound by slot blot. The filters were hybridized for $4 \mathrm{~d}$ at $42^{\circ} \mathrm{C}$, washed according to standard techniques, and autoradiographed.

$\left[{ }^{3} H\right]$ Thymidine incorporation. DNA synthesis was estimated by $\left[{ }^{3} \mathrm{H}\right]$ thymidine incorporation over the 1-h period before death. $0.5-\mathrm{g}$ pieces of liver were homogenized in $0.25 \mathrm{M}$ sucrose with $1 \mathrm{mM} \mathrm{MgCl}$ and then precipitated with 5\% TCA. The tritium radioactivity of the precipitates was measured and expressed as disintegrations per minute per milligram DNA, per milligram protein and per gram of liver weight $(12,25)$. DNA content in the liver homogenates was estimated fluorometrically as described by Labarca and Paigen (36). The incorporation of $\left[{ }^{3} \mathrm{H}\right]$ thymidine into DNA has been validated as an excellent measure of DNA synthesis in liver regeneration (37). However, autoradiography was done for additional confirmation. Coded histologic sections from each rat were reviewed to determine the percentage of labeled nuclei. At least 500 nuclei were counted per section and a labeling index was derived by dividing the number of labeled nuclei by the total number of nuclei counted and then multiplying by $100(25,38)$.

Calculation of liver mass restoration. The weight of the liver segment resected at partial hepatectomy was taken as $70 \%$ of the total prehepatectomy liver weight. Thus, the total prehepatectomy liver weight was calculated as $(100 / 70) \times$ resected liver weight. The expected weight of the unresected liver remnant was therefore $(30 / 100) \times$ the prehepatectomy liver weight. At the time of death, the liver remnant was weighed. The percentage of the prehepatectomy liver weight that was regained $24 \mathrm{~h}$ after surgery was calculated as: [actual weight of liver remnant - expected weight of liver remnant $] \div$ prehepatectomy liver weight $\times 100(25)$.

Statistical analysis. Data were analyzed by analysis of variance, Student's $t$ test, and linear regression analysis (39).

\section{Results}

As shown in Fig. 1, hepatic ODC activities were virtually identical in ethanol-fed rats and pair-fed controls immediately

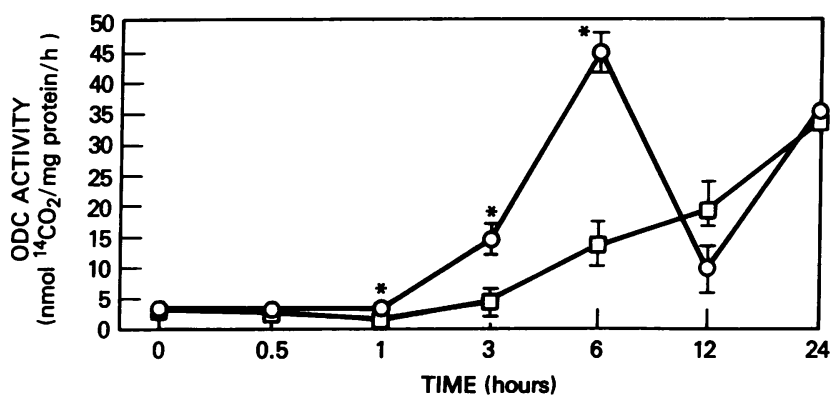

Figure 1. Hepatic ornithine decarboxylase (ODC) activity (nanomoles $\mathrm{CO}_{2}$ released/milligram protein/hour) in ethanol-fed rats and pair-fed controls after partial hepatectomy. Tissue was obtained from rats that had been fed diets containing either $36 \%$ ethanol or an isocaloric amount of carbohydrate for 6 wk before partial hepatectomy. Livers were snap frozen with liquid nitrogen and stored at $-70^{\circ} \mathrm{C}$ for no more than $2 \mathrm{wk}$ until analysis. Tissue from ethanol treated and control rats were assayed concurrently as described under Methods. The final reaction mixture $(500 \mu \mathrm{l})$ contained $0.1 \mathrm{mM}$ unlabeled ornithine, $1 \mu \mathrm{Ci}\left[1-{ }^{14} \mathrm{C}\right]$ ornithine $(20 \mathrm{mCi} / \mathrm{mmol}), 0.1 \mathrm{mM}$ PLP, and $300 \mu \mathrm{l}$ of a $100,000 \mathrm{~g}$ supernatant of liver homogenized in $100 \mu \mathrm{M}$ sodium phosphate buffer containing $5 \mathrm{mM}$ DTT. Each point represents the mean \pm SD of data in nine rats from three separate but similar experiments. ${ }^{*} P<0.05$ (at $1 \mathrm{~h}$ ) or $P<0.01$ (at 3 and $6 \mathrm{~h}$ ) vs. pair-fed controls. before $\mathrm{PH}$. In control rats, ODC activity peaked biphasically after PH. In contrast, induction of ODC activity after PH was blunted in ethanol-fed rats. In this group, the early peak in ODC activity did not occur. Instead, ODC activity gradually increased until it reached control levels by $24 \mathrm{~h}$ after PH. ODC activity in ethanol fed rats was significantly less than control at 1,3 , and $6 \mathrm{~h}$. Putrescine levels were measured in order to determine if ethanol-associated inhibition of ODC activity was also associated with reduced hepatic levels of polyamines. As shown in Fig. 2, putrescine levels were similar in ethanol and control rats before and for the first hour after PH. However, by $3 \mathrm{~h}$ putrescine levels in ethanol-fed rats were significantly less than those of control animals. They remained below control values until $12 \mathrm{~h}$ after PH. In both ethanol and control rats, ODC activity was significantly correlated with putrescine levels $(r=0.8-0.9, P<0.01)$.

Because putrescine is the substrate for spermidine and spermine synthesis, levels of these polyamines were also measured. Spermidine concentration tended to be greater in ethanol-fed than control rats before $\mathrm{PH}$. In marked contrast to the significant increase in spermidine levels that occurred in control rats over the first $12 \mathrm{~h}$ after $\mathrm{PH}$, spermidine levels remained virtually unchanged in ethanol-treated animals (Fig. 3). Changes in spermine concentration after partial hepatectomy paralleled those of spermidine (Fig. 4).

These data suggest that chronic ethanol consumption inhibits both ODC activity and the synthesis of polyamines. To determine if ethanol-induced inhibition of ODC activity was due to reduced levels of ODC apoenzyme, ODC mRNA expression and levels of ODC apoenzyme were measured. Expression of ODC mRNA before and after partial hepatectomy is illustrated in Fig. 5. The major hybridizing band at $2.1 \mathrm{~kb}$ is consistent with published results $(40,41)$. Our probe also identified a minor band at $2.4 \mathrm{~kb}$. Although ODC mRNA expression markedly increased after PH in both control and ethanol fed groups at 12 and $24 \mathrm{~h}$, there were no significant differences between the two groups. These data suggest that ethanol does not inhibit the transcription of ODC mRNA at the times indicated. Interestingly, although there was a significant increase in ODC mRNA levels at 12 and $24 \mathrm{~h}$ post-PH,

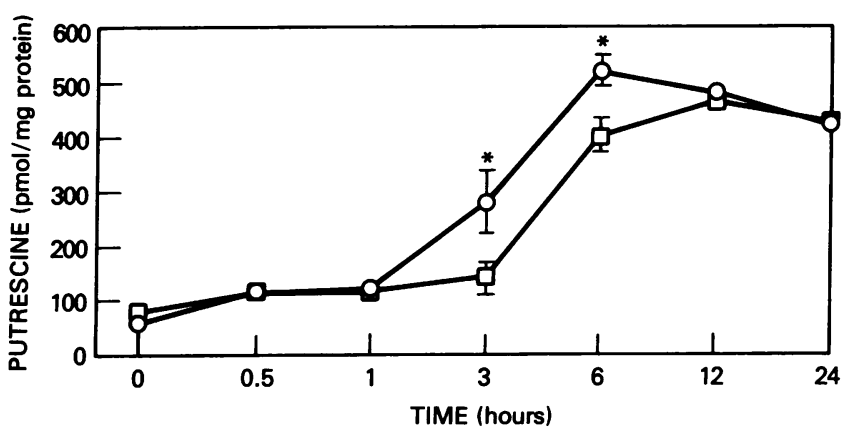

Figure 2. Hepatic putrescine concentrations (picomoles per milligram protein) in ethanol- and pair-fed rats after partial hepatectomy. Tissue was obtained as described in the legend to Fig. 1. Dansylated derivatives of the diamine were measured in neutralized, acid-precipitated $100,000 \mathrm{~g}$ liver extracts using the reversed phase ion-pair HPLC method described in Methods. 1,6-diaminohexane was used as an internal standard and each specimen was run in triplicate to ensure reproducibility. Each point represents the mean \pm SD of data in nine rats from three separate but similar experiments. ${ }^{*} P<0.05$ vs. ethanol-fed rats and $<0.01$ vs. zero time. 


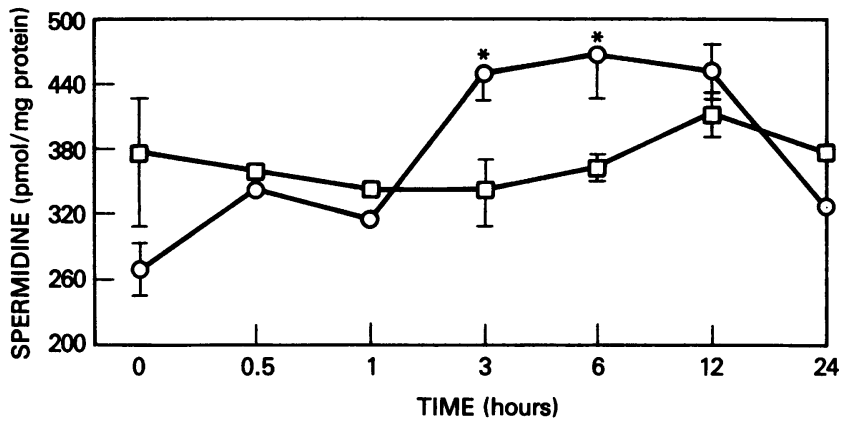

Figure 3. Hepatic spermidine concentrations (picomole per milligram protein) in ethanol- and pair-fed rats after partial hepatectomy. Techniques for tissue extraction and chromatography are as described for Fig. 2. Each point represents the mean \pm SD of data in nine rats from three separate but similar experiments. ${ }^{*} P<0.05$ vs. ethanol fed rats and $<0.01$ vs. zero time.

nuclear run-offs showed no significant change in in vitro transcription of ODC at $0,6,12$, and $24 \mathrm{~h}$ in either group (data not shown).

Since tissue content of ODC may not always reflect ODC mRNA expression, levels of ODC apoenzyme were measured. By using an established technique to measure DFMO binding, the equivalent amount of ODC apoenzyme was determined (30). The amount of ODC apoenzyme in ethanol rats was similar to that of control rats both before and after PH (Table I). These data suggest that ethanol inhibition of ODC activity cannot be explained by reduced synthesis or levels of ODC apoenzyme and hence, may result from posttranslational inactivation of the enzyme.

As shown in Fig. 6, ethanol significantly inhibited DNA synthesis and liver regeneration $24 \mathrm{~h}$ after partial hepatectomy. Supplemental putrescine significantly increased hepatic putrescine levels during the initial $6 \mathrm{~h}$ after PH in both ethanol and pair fed rats (data not shown). The effect of putrescine therapy on liver regeneration in controls was comparable to that of normal saline treatment. However, in ethanol-fed rats, supplemental putrescine $(4 \mathrm{mg} / \mathrm{kg}$ body $\mathrm{wt})$ significantly increased $\left[{ }^{3} \mathrm{H}\right]$ thymidine incorporation/mg hepatic DNA and the nuclear labeling index. Restoration of liver mass was also improved.

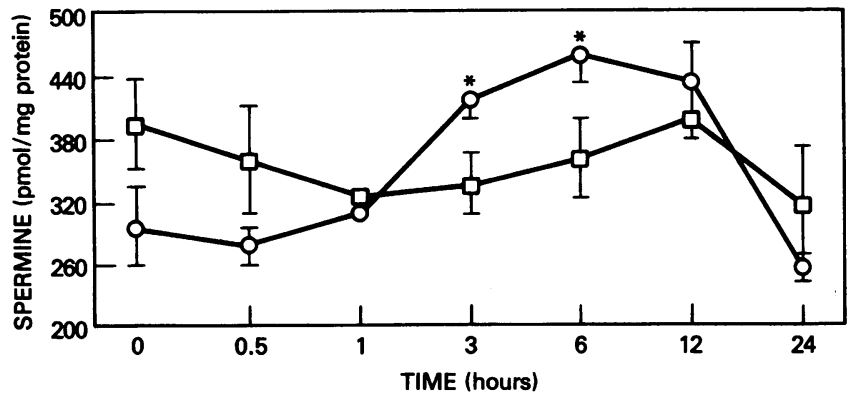

Figure 4. Hepatic spermine concentrations (picomole per milligram protein) in ethanol- and pair-fed rats fed rats after partial hepatectomy. Techniques for tissue extraction and chromatography are as described for Fig. 2. Each point represents the mean \pm SD of data in nine rats from three separate but similar experiments. ${ }^{*} P<0.05$ vs. ethanol fed rats and $<0.01$ vs. zero time.

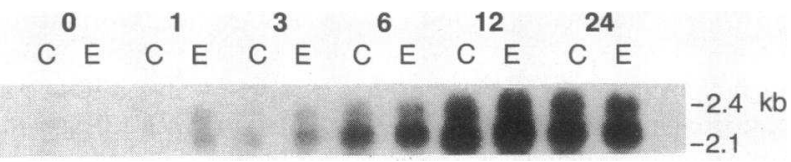

Figure 5. Northern blot hybridization analysis of ODC mRNA. Poly $(A+)$ enriched mRNA from rat livers was separated by formaldehyde-agarose gel electrophoresis, transferred to a nitrocellulose filter, and hybridized with an ODC CDNA probe as described under Methods. Expression of ODC mRNA in control (C) and ethanol (E) rats before and at various times $(1,3,6,12$, and $24 \mathrm{~h})$ after partial hepatectomy is shown on this autoradiogram. ODC mRNA is demonstrated by the major hybridizing band at $2.1 \mathrm{~kb}$.

\section{Discussion}

Alcoholic liver injury is a major cause of chronic liver disease in industrialized societies (42). Even in subjects without obvious liver disease, habitual alcohol consumption is ubiquitous in many of these populations (43). Since regeneration is essential for recovery from many forms of liver injury, the effect of chronic ethanol consumption on the regenerative capacity of the hepatocyte has many clinically relevant implications.

This study was devised to define potential mechanisms responsible for the anti-regenerative effects of chronic ethanol consumption. Partial hepatic resection was used to trigger liver regeneration because it is highly reproducible and has been extensively studied, permitting clear definition of the normal sequence of regenerative events (28). Despite previous data, which suggested that chronic exposure to ethanol does not adversely affect polyamine synthesis $(24,25)$, this process was carefully scrutinized because it is known to be essential for hepatic regeneration (12-14) and is acutely inhibited by ethanol (21-23).

Table I. ODC Apoenzyme Concentrations after Partial Hepatectomy

\begin{tabular}{ccc}
\hline Group & Time & ODC apoenzyme concentration \\
\hline & $h$ & $n m o l / m g$ protein \\
Ethanol & 0 & $31.8 \pm 9.6$ \\
Control & & $29.8 \pm 7.4$ \\
Ethanol & 1 & $29.4 \pm 5.0$ \\
Control & & $40.7 \pm 8.6$ \\
Ethanol & 3 & $65 \pm 4.0$ \\
Control & & $68 \pm 6.1$ \\
Ethanol & 6 & $58.5 \pm 7.5$ \\
Control & & $72.0 \pm 10.0$ \\
Ethanol & 12 & $33.0 \pm 10.6$ \\
Control & & $14.3 \pm 8.7$ \\
Ethanol & 24 & $31.8 \pm 9.8$ \\
Control & & $33.0 \pm 4.1$
\end{tabular}

ODC apoenzyme concentrations were determined in liver homogenates by measuring the binding of tritium-labeled difluoromethylornithine, a specific, irreversible inhibitor of ODC. Values at each time represent the mean $\pm \mathrm{SD}$ of at least nine rats from each group. 


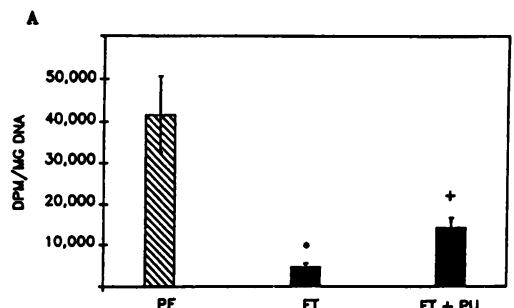

B
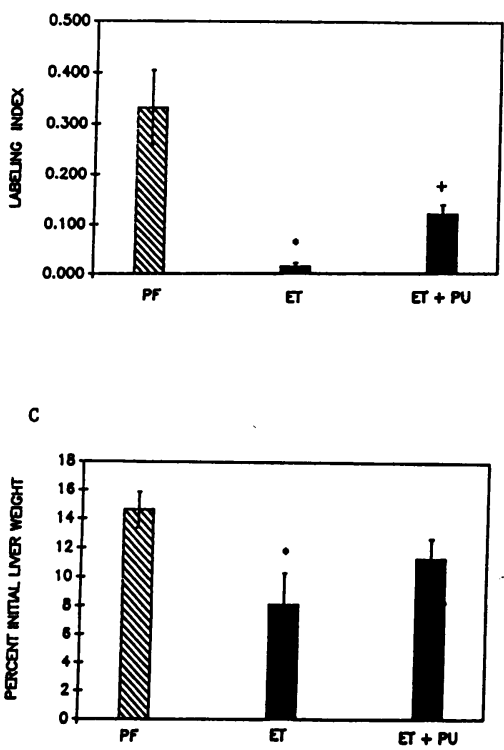

Figure 6. Effect of supplemental putrescine on parameters of liver regeneration $24 \mathrm{~h}$ after partial hepatectomy. Rats received either saline or putrescine (4 $\mathrm{mg} / \mathrm{kg}$ ) intraperitoneally at the time of partial hepatectomy and 4 and $8 \mathrm{~h}$ thereafter Since the effects of putrescine on regeneration were similar to those of saline in pair fed rats, data from these groups $(n=15)$ have been combined (PF). Data in ethanol rats treated with saline (ET, $n=15$ ) and in those treated with putrescine (ET $+\mathrm{PU}, n=30$ ) are shown separately. $(A)$ Hepatic incorporation of $\left[{ }^{3} \mathrm{H}\right]$ thymidine. Tritium radioactivity/mg hepatic DNA was determined as described in Methods. ${ }^{*} P<0.002$ vs. $P F,{ }^{+} P<0.005$ vs. ET. (B) Nuclear labeling with $\left[{ }^{3} \mathrm{H}\right]$ thymidine. Autoradiography was done and the nuclear labeling index was assessed as described in the Methods. ${ }^{*} P<0.005$ vs. PF, ${ }^{+} P<0.002$ vs. ET. $(C)$ Restoration of liver mass was determined by calculating the percentage of preoperative liver weight that had been regained by $24 \mathrm{~h}$ after partial hepatectomy as described in Methods. ${ }^{*} P<0.02$ vs. PF.

In the model used, chronic ethanol consumption clearly delays the induction of ODC activity that normally occurs after PH. Previous studies, which failed to document any inhibitory effect of chronic ethanol exposure on ODC activity, probably overlooked this inhibition because tissues were studied either before or long after the regenerative stimulus was applied. In ethanol-fed rats, as in many other models in which ODC activity is inhibited, the inhibition of enzyme activity is highly correlated with reduced polyamine levels, impaired DNA synthesis and cellular proliferation $(12,13,44,45)$. Even the transient delay in polyamine synthesis associated with ethanol consumption appears to be pathophysiologically significant. This is demonstrated by the finding that supplemental polyamines dramatically improve DNA synthesis in polyamine-deficient, ethanol-fed rats.

Despite significant differences in ODC activity between ethanol-fed and control animals during the initial $6 \mathrm{~h}$ after $\mathrm{PH}$, expression of ODC mRNA and the concentration of ODC apoenzyme were similar in both groups at all time points assessed. Since $\left[{ }^{3} \mathrm{H}\right]$ DFMO may bind to non-ODC proteins under certain assay conditions, the present apoenzyme data must be confirmed using immunoprecipitation techniques. If substantiated, these observations indicate that ethanol inhibition of ODC activity occurs at neither transcriptional nor translational levels. This suggests that chronic ethanol consumption affects posttranslational inhibition of ODC activity.

It is unclear how this posttranslational inactivation occurs. Because chronic ethanol consumption reduces plasma and tissue concentrations of PLP (46), a factor necessary for ODC activity (47), it is tempting to speculate that posttranslational inhibition of ODC activity is due to PLP deficiency. However, while PLP deficiency may contribute to ethanol-associated inhibition of polyamine synthesis in vivo, it cannot explain the inhibition of ODC activity noted in the present study. In these experiments, ODC activity was determined in vitro using standard assay conditions that optimize PLP concentrations (48). Hence, the reduced activity of ODC noted in tissues of chronically ethanol-fed rats cannot be explained by PLP deficiency.

ODC can be posttranslationally modified by various mechanisms including noncovalent binding to an inhibitory "antizyme," microsomal oxidation, transglutamination and phosphorylation $(49,50)$. Each of these processes is induced by elevated tissue levels of particular polyamines. Basal levels of spermidine and spermine tended to be elevated in ethanoltreated animals. These two polyamines have been shown to induce a kinase that inactivates ODC by phosphorylation (51). Some workers have suggested that the phosphorylated ODC and the polyamine-dependent kinase are also regulatory proteins that can affect the expression of genes involved in cellular proliferation (20).

The identification of an ethanol-associated defect in polyamine synthesis, a vital step in hepatic regeneration, will help delineate the effects of chronic ethanol consumption on cellular proliferation. Such knowledge may suggest therapuetic approaches to improve the hepatic regenerative capacity of alcoholic individuals. These efforts, in turn, may improve the morbidity and mortality of alcoholic liver disease.

\section{Acknowledgments}

This research was supported in part by grants from the Alcoholic Beverage Medical Research Foundation and the Veterans Administration.

\section{References}

1. Leevy, C. M. 1963. In vitro studies of hepatic DNA synthesis in percutaneous liver biopsy specimens. J. Lab. Clin. Med. 61:761-779.

2. Wands, J. R., E. A. Carter, N. L. R. Bucher, and K. J. Isselbacher. 1979. Inhibition of hepatic regeneration in rats by acute and chronic ethanol intoxication. Gastroenterology. 77:528-531.

3. Dugay, L., D. Couter, C. Hetu, and J. G. Joly. 1982. Inhibition of liver regeneration by chronic alcohol administration. Gut. 23:8-13.

4. Frank, W. O., A. N. Rayes, A. Washington, and P. R. Holt. 1979. Effect of acute ethanol administration upon hepatic regeneration. $J$. Lab. Clin. Med. 93:402-413.

5. Orrego, H., I. R. Crossley, V. Saldiva, A. Medline, G. Varghese, and Y. Israel. 1981. Long-term ethanol administration and short- and long-term liver regeneration after partial hepatectomy. J. Lab. Clin. Med. 97:221-230.

6. Carter, E. A., and J. R. Wands. 1985. Ethanol inhibits hormone stimulated hepatocyte DNA synthesis. Biochem. Biophys. Res. Commun. 128:767-774.

7. Lad, P. J., W. T. Shier, H. Skelly, and B. deHemptinne. 1982. Adult rat hepatocytes in primary culture. VII. Proliferative and functional properties of cells from ethanol intoxicated animals: evidence for a reversible albumin production defect. Alcohol. Clin. Exp. Res. 6:72-79.

8. Milandri, M., J. Gaub, and L. Ranek. 1980. Evidence for liver cell proliferation during fatal acute liver failure. Gut. 21:423-427. 
9. Terblance, J., and T. E. Starzl. 1979. Hepatic regeneration: implications in fulminant hepatic failure. Int. J. Artif. Organs. 2:49-52.

10. Farivar, M., J. R. Wands, and K. J. Isselbacher. 1976. Effect of insulin and glucagon on fulminant murine hepatitis. N. Engl. J. Med. 296:1517-1519.

11. Popper, H. 1979. Injury and repair of liver cells. Med. Clin. N. Am. 63:479-493.

12. Luk, G. D. 1986. Essential role of polyamine metabolism in hepatic regeneration. Inhibition of deoxyribonucleic acid and protein synthesis and tissue regeneration by difluoromethylornithine in the rat. Gastroenterology. 90:1261-1267.

13. Poso, H., and A. E. Pegg. 1982. Effect of a-difluoromethylornithine on polyamine and DNA synthesis in regenerating rat liver: reversal of inhibition of DNA synthesis by putrescine. Biochim. Biophys. Acta. 696:179-186.

14. Tabor, C. W., and H. Tabor. 1984. Polyamines. Annu. Rev. Biochem. 53:749-790.

15. Fillingame, R. H., D. M. Jorstat, and D. R. Morris. 1975. Increased cellular levels of spermidine or spermine are required for optimal DNA synthesis in lymphocytes activated by conconavalin A. Proc. Natl. Acad. Sci. USA. 72:4042-40455.

16. Janne, J., H. Poso, and A. Raina. 1978. Polyamines in rapid growth and cancer. Biochim. Biophys. Acta. 473:241-293.

17. Keuhn, G. D., H. U. Affolter, V. J. Atmar, T. Seebeck, U. Gubler, and R. Braun. 1979. Polyamine mediated phosphorylation of a nucleolar protein from Physarum polycephalum that stimulates rRNA synthesis. Proc. Natl. Acad. Sci. USA. 76:2541-2545.

18. Jacob, S. T., B. W. Duceman, and K. M. Rose. 1981. Spermine mediated phosphorylation of RNA polymerase $I$ and its effect on transcription. Med. Biol. 59:381-388.

19. Stein, G. S., T. C. Spelsberg, and L. J. Kleinsmith. 1974. Nonhistone chromosomal proteins and gene regulation. Science (Wash. DC). 183:817-824.

20. Luscher, B., and R. N. Eisenman. 1988. c-myc and c-myb protein degradation: effect of metabolic inhibitors and heat shock. Mol. Cell. Biol. 8:2504-2512.

21. Poso, A., and H. Poso. 1980. Inhibition of ornithine decarboxylase in regenerating rat liver by acute ethanol treatment. Biochim. Biophys. Acta. 606:338-346.

22. Lumeng, L. 1979. Hormonal control of ornithine decarboxylase in isolated liver cells and the effect of ethanol oxidation. Biochim. Biophys. Acta. 587:556-566.

23. Oratz, M., M. A. Rothschild, S. S. Schreiber, A. Burks, J. Mongelli, and B. Matarese. 1983. The role of the urea cycle and polyamines in albumin synthesis. Hepatology. 3:567-571.

24. Poso, H., and A. R. Poso. 1980. Stabilization of tyrosine aminotransferase and ornithine decarboxylase in regenerating rat liver by ethanol treatment. FEBS (Fed. Eur. Biochem. Soc.) Lett. 113:211214.

25. Diehl, A. M., M. A. Chacon, and P. Wagner. 1988. The effect of chronic ethanol feeding on ornithine decarboxylase activity and liver regeneration. Hepatology. 8:237-242.

26. Lieber, C. S., and L. M. DeCarli. 1982. The feeding of alcohol in liquid diets: two decades of applications and 1982 update. Alcohol. Clin. Exp. Res. 6:523-531.

27. Higgins, G. M., and R. M. Anderson. 1931. Experimental pathology of liver: restoration of liver of the white rat following partial surgical removal. Arch. Pathol. 12:186-202.

28. Bucher, N. L. R., and R. A. Malt. 1973. Regeneration of the Liver and Kidney. Little, Brown, \& Co., New York.

29. Luk, G. D., and S. B. Baylin. 1984. Inhibition of intestinal epithelial DNA synthesis and adaptive hyperplasia after jejunectomy in the rat by suppression of polyamine biosynthesis. J. Clin. Invest. 74:698-704.

30. Seely, J. E., H. Poso, and A. E. Pegg. 1982. Measurement of the number of ornithine decarboxylase molecules in rat and mouse tissues under various physiological conditions by binding of radiolabeled adifluoromethylornithine. Biochem. J. 206:311-318.
31. Brown, N. D., R. B. Sweet, J. A. Kintzios, H. D. Cox, and B. P. Doctor. 1979. Determination of 5-dimethylaminonapthalene-1-sulfonyl derivatives of urinary polyamines by high performance liquid chromatography. J. Chromatogr. 164:35-40.

32. Bradford, M. M. 1972. A rapid and sensitive method for the quantitation of microgram quantities of protein utilizing the principle of protein-dye binding. Anal. Biochem. 27:246-254.

33. McConlogue, L., M. Gupta, L. Wu, and P. Coffino. 1984. Molecular cloning and expression of the mouse ornithine decarboxylase gene. Proc. Natl. Acad. Sci. USA. 81:540-544.

34. Holland, E. C., J. O. Leung, and K. Drickamer. 1984. Rat liver asialoglycoprotein receptor lacks a cleavable NH2-terminal signal sequence. Proc. Natl. Acad. Sci. USA. 81:7338-7342.

35. Huber, B. E., T. B. Glowinski, and S. S. Thorgeirsson. 1986. Transcriptional and post-transcriptional regulation of the asialoglycoprotein receptor in normal and neoplastic rat liver. J. Biol. Chem. 261:12400-12407.

36. Labarca, C., and A. Paigen. 1980. A simple, rapid, and sensitive DNA assay procedure. Anal. Biochem. 102:344-351.

37. Digernes, V., G. Bronstad, T. E. Sand, and T. Christofferson. 1982. The proliferative response of rat liver parenchymal cells after partial hepatectomy. A methodological study comparing flow cytometry of nuclear DNA content in vivo and in vitro uptake of thymidine. Cell. Tissue Kinet. 15:521-528.

38. McDonald, R. A., and F. K. Mallory. 1958. Autoradiography using tritiated thymidine. Lab. Invest. 8:1547-1562.

39. Snedecor, G. W., and W. G. Cochran. 1967. Statistical Methods. 6th ed. Iowa State University Press, Ames, IA.

40. Berger, F. G., P. Szymanski, E. Read, and G. Watson. 1984. Androgen-regulated ornithine decarboxylase mRNA's of mouse kidneys. J. Biol. Chem. 259:7941-7946.

41. Kahana, C., and D. Nathans. 1985. Translational regulation of mammalian ornithine decarboxylase by polyamines. J. Biol. Chem. 260:15390-15393.

42. Schmidt, W., and J. DeLint. 1972. Causes of death of alcoholics. Q. J. Stud. Alcohol. 33:171-185.

43. Facts About Alcohol and Alcoholism. 1974. DHEW Publication No. (ASM)75-31. National Institute on Alcohol Abuse and Alcoholism, Rockville, MD.

44. Nishiguchi, S., S. Otani, I. Matsui-Yuasa, and S. Morisawa 1988. Inhibition of ornithine decarboxylase induction of interferon (a and B) and its reversal by dibutyric adenosine 3',5'-monophosphate. Eur. J. Biochem. 172:287-292.

45. Nishiguchi, S., S. Otani, I. Matsui-Yuasa, S. Morisawa, T. Monna, T. Kieroki, K. Kobayashi, and S. Tamamoto. 1986. Inhibition by interferon ( $a$ and $b)$ of mouse liver regeneration and its reversal by putrescine. FEBS (Fed. Eur. Biochem. Soc.) Lett. 205:61-65.

46. Majumdar, S. K., G. K. Shaw, P. O. Gorman, E. J. Aps, E. L. Offerman, and A. D. Thomson. 1982. Blood vitamin status (B1, B2, B6, folic acid and B12) in patients with alcoholic liver disease. Int. J. Vitam. Nutr. Res. 52:266-271.

47. Hunter, J. E., and A. E. Harper. 1976. Stability of some pyridoxal phosphate-dependent enzymes in vitamin B-6 deficient rats. $J$. Nutr. 106:653-664.

48. Russell, D. H. 1985. Ornithine decarboxylase: A key regulatory enzyme in normal and neoplastic growth. Drug Metab. Rev. 16:1-88.

49. Cannellakis, E. S., D. A. Kyriakidis, C. A. Rinehart, S. C. Huang, C. Pangiotidis, and W. F. Fong. 1985. Regulation of polyamine biosynthesis by antizyme and some recent developments relating the induction of polyamine biosynthesis to cell growth. Rev. Biosci. Rep. 5:189-204.

50. Hayashi, S. I., T. Kameji, K. Fujita, Y. Murakami, R. Danamoto, K. Utsunomiya, S. Matusfuji, M. Takiquchi, M. Mori, and M. Tatibana. 1985. Molecular mechanism for the regulation of hepatic ornithine decarboxylase. Adv. Enzymol. 5:311-329.

51. Keuhn, G. D., and V. J. Atmar. 1982. Post-translational control of ornithine decarboxylase by polyamine dependent kinase. Fed. Proc. 41:3078-3083. 